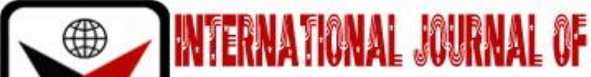



ISSN 2278 - 0211 (Online)

\section{Assessment of Chemical Toxicity and Radiological Toxicity of Uranium Associated with Drinking Water in Kuye, Ogbomoso, Nigeria}

O. O. Oladapo
Lecturer, Department of Science Laboratory Technology,
Ladoke Akintola University of Technology, Nigeria
O. M. Oni
Professor, Department of Pure and Applied Physics,
Ladoke Akintola University of Technology, Nigeria
A.E. Oni
Lecturer, Department of Physics with Electronics,
Oduduwa University Ipetumodu, Nigeria
A. O. Adelodun
A. A. Aremu
Lecturer, Department of Physicsallmark University, Nigeria
Lecturer, Department of Pure and Applied Physics,
Ladoke Akintola University of Technology, Nigeria
I. D. Olatunde
Lecturer, Department of Physics with Electronics,
Oduduwa University Ipetumodu, Nigeria
O.P. Oyero
Instructor, Department of Pure and Applied Physics,
Ladoke Akintola University of Technology, Nigeria
M.K. Lawal
Lecturer, Department of Science Laboratory Technology,
Ladoke Akintola University of Technology, Nigeria

\begin{abstract}
:
The activity concentration of uranium in bottled and well water samples in Kuye area, Ogbomoso, Nigeria were measured using gamma ray spectroscopy method. The mass concentration values of both the bottled water samples and the well water samples exceeded the recommended safe limit of uranium in drinking water of $30 \mu \mathrm{g} . \mathrm{l}-1$ by WHO. All the water samples investigated had their excess cancer mortality risk lower than the permissible limit of 10-3.The excess cancer morbidity risk associated with the intake of uranium in the drinking water samples investigated shows that only $80 \%$ of the bottled water sample and $22 \%$ of the well water samples were safe for drinking. All the water samples investigated were found to be unsafe for consumption in terms of their chemical risk as they all exceeded the hazard quotient of unity ranging from 12.55 to 34.14. The risk associated with drinking bottled water and well water in Iluju, Ogbomoso is due to cancer morbidity risk and chemical toxicity risk. Therefore, the study suggest that the consumption of bottled water and well water by the local people of Kuye may pose serious threat to their health.
\end{abstract}

Keywords: Uranium, radiological toxicity, chemical toxicity, bottled water, well water

\section{Introduction}

Uranium occurs naturally in the earth's crust and is a radioactive and radionuclide mineral. Uranium can be found in air. Water, rocks and soil. It can also be found in other natural materials. Uranium that occurs naturally is present in soil and bedrock in many parts of Nigeria. Uranium can enters the human body by ingestion and by inhalation of uraniumcontaining dust particles or aerosols. There are several ways by which uranium can come into contact with water. Uranium can enter the water body from deep within the ground in form of seepage, erosion or through human activities such as mining. Uranium is absorbed into the groundwater as the groundwater moves through the earth. The absorbed uranium accounts for its presence in the water bodies. The hexavalent state of uranium commonly associated with $\mathrm{UO}_{2}{ }^{2+}$ is 
more significant in water, whereas this state of uranium is insoluble in almost all tetravalent compounds (Sahoo et al., 2009).

Damage can be done to the gastrointestinal tracts when uranium is ingested through drinking water. The concentration of uranium can move through the lung tissue to the blood stream. This will later be stored in the liver, kidney, bone or other tissues for years, irradiating all tissues located near its storage place. When the concentrations of uranium in drinking water is above the permissible limits, it may produce harmful biological effects in humans (WHO, 2008). The World Health Organization (WHO, 2004) had earlier recommended a reference level $15 \mu \mathrm{gl}-1$ but now the permissible limit of uranium in drinking water by WHO is $30 \mu \mathrm{gl}^{-1}$ (WHO, 2011).

Uranium is a radionuclide which is known for both its chemical toxicity and radiological toxicity. The health effects of uranium are of two types: carcinogenic and non-carcinogenic effects. The risk is both radiological toxicity (carcinogenic) due to radiation of uranium isotopes and the chemical toxicity (non-carcinogenic) due to uranium as a heavy metal (WHO, 1998) Studies have shown toxic effects of uranium on kidneys and bones of mices (Kurttio et al., 2002). Reduction in maternal weight gain, reduction in daily feed intake and increase in liver weight are some of the effects observed in mices (Larivière et al., 2007; Zamora et al., 1998). The major health challenge related to uranium ingestion is chemical toxicity which affects humans and animals, with the kidney being the target organ (Leggett, 1989; Guglielmotti et al., 1989; Keith et al., 1999).

Ogbomoso town lies within $4^{\circ} 10^{\prime} \mathrm{E}$ to $4^{\circ} 20^{\prime}$ E longitude and $8^{\circ} 00^{\prime} \mathrm{N}$ to $8^{\circ} 15^{\prime} \mathrm{N}$ latitude (Fig.1). Iluju in Ogbomoso is located in the North Eastern region of the city with underlining geology mainly of granite (Fig. 1). Iluju in Ogbomoso is recognized for its quarry activities. It is worthy of note that Iluju in Ogbomoso do not have access to tap water supply. The major drinking water to the population is well water and seldomly sachet and bottled water. However, there is no known data on the radiological and chemical risk assessment. Therefore, this study was carried out in order to investigate the health risk and to provide data on the concentration of uranium in wells and bottled water and the associated radiological risk and chemical toxicity to the population of Kuye in Ogbomoso.

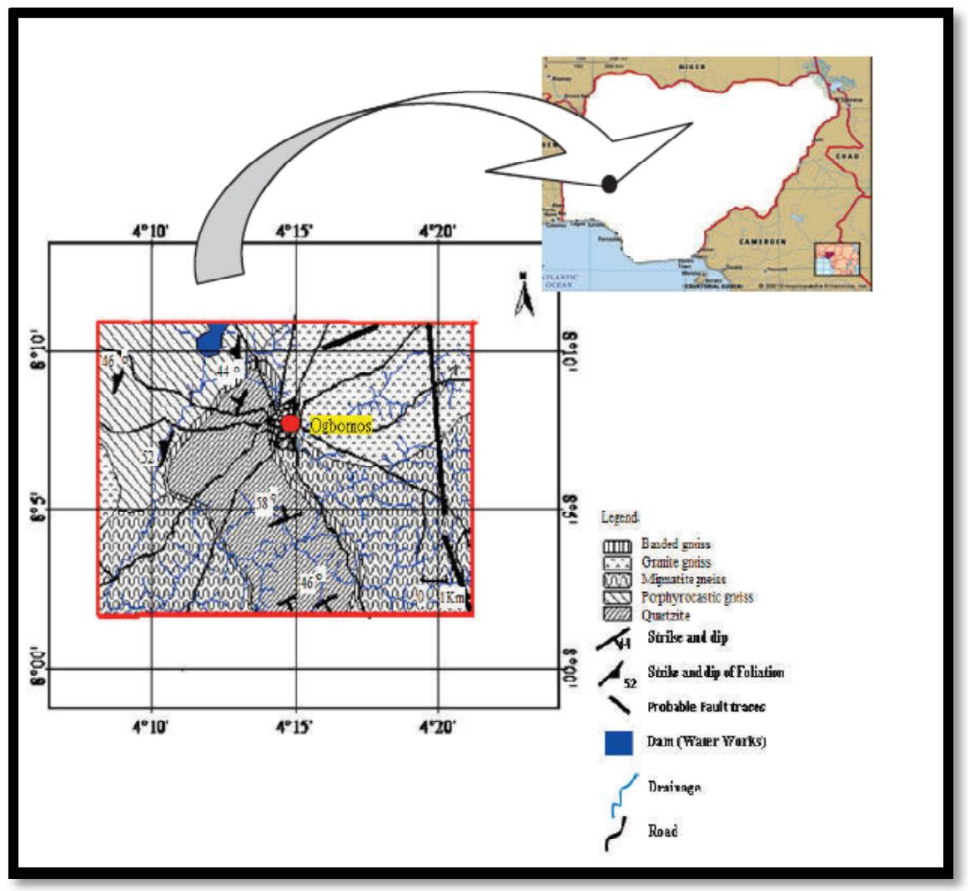

Figure 1: The Location of Ogbomoso Metropolis (REF)

\section{Materials and Method}

\subsection{Sampling and Preparation}

The sampling area for this study is Kuye located in the North East region of the city of Ogbomoso. The major drinking water to the population is well water. During raining seasons, they depend on rain water collected from roof tops and occasionally during celebrations, the people usually have access to sachet water and bottled water. In this present study, 72 water samples: Bottled water (45) and well water (27) in the region of Kuye in Ogbomoso were analysed to assess the chemical and radiological toxicity. The water samples were collected with 1 L-size plastic containers which has been previously washed and rinsed with dilute acid $(0.1 \mathrm{M} \mathrm{HCl})$. The collected samples were acidified with 1 M concentrated $\mathrm{HCl}$ to obtain a $\mathrm{pH}<2$ in order to avoid adsorption of the radionuclide on the walls of the container (AS/NZS, 1998). The samples were subsequently taken to the laboratory for preparation prior to gamma spectroscopy.

\subsection{Measurement}

In this analysis, gamma ray spectroscopy method was adopted. The spectrometer used for gamma counting consists of a highly-shielded Canberra $\mathrm{NaI}$ (Tl) detector enclosed in a $100 \mathrm{~mm}$ thick lead blocks coupled to a Canberra 
Multichannel Analyzer (MCA) with a PC via an interface. The collector is located in the center of the lead shield in order to minimize the effect of scattered radiation from the shield (UNSCEAR, 1982). The Energy and Efficiency calibration of the gamma spectrometer were carried out using the International Atomic Energy Agency (IAEA) reference source material. Accurate energy and efficiency of the gamma spectroscopy system were made quantity radionuclides present in the sample since the accuracy of all quantitative results depend on the attainable accuracy of the systems calibration. The transition line of $1460 \mathrm{keV}$ for ${ }^{40} \mathrm{~K}, 1764 \mathrm{keV}$ for ${ }^{214} \mathrm{Bi}$ and $2614 \mathrm{keV}$ of ${ }^{208} \mathrm{Ti}$ were used to determine the concentration ${ }^{40} \mathrm{~K}$, ${ }^{238} \mathrm{U}$ and ${ }^{232} \mathrm{Th}$ respectively. Finally, counting was carried out for a period of 36000 s, first with an empty Marinelli beaker of identified geometry as the sample to determine the background spectrum. Thereafter, the sealed sample of water were counted for the same period of 36000s.

The activity concentrations of the water samples were determined using the total net counts under the selected photopeaks, the measured photopeak efficiency, gamma intensity and mass of the samples. After correcting for background and Compton contribution, the activity concentrations of ${ }^{232} \mathrm{Th},{ }^{238} \mathrm{U}$ and ${ }^{40} \mathrm{~K}$ were determined. From the net area, the activity concentrations in the samples were obtained using (Jibiri et al., 1999; Awudugba and Techokossa, 2008): $\operatorname{Ac}\left(B q . l^{-1}\right)=k C_{n}$

Where $k=\frac{1}{\varepsilon P_{\gamma} V_{S}}$

$\mathrm{A}_{c}$ is the activity concentration of the radionuclide in the sample given in $\mathrm{Bq}^{-1}, C_{n}$ is the count rate under the corresponding peak, $\varepsilon$ is the detector efficiency at the specific gray energy, $P$ is the absolute transition probability of the specific gray energy, and $V_{s}$ is the volume of the sample $(I)$. The detailed calibration procedures of the detector can be found in the publications (Jibiri et al., 1999, Jibiri et al., 2007, 2009). Using equation 1, the activity concentrations of uranium in each of the water samples were determined.

\subsection{Determination of Mass Concentration of Uranium}

Testing for the presence of uranium in drinking water can be done using several methods approved by USEPA. Depending on the analytical method, uranium can be measured either as the activities of the radionuclides where the result are reported in $\left(p C i . l^{-1}\right)$, or uranium can be measured as the mass of the isotope and the result are reported in $m g . l^{-1}$ or $\mu g . l^{-1}$

In this study, uranium is measure as the activity of radionuclide where the result are reported in $B q . l^{-1}$. The data for the activity concentrations of the uranium were converted to the uranium mass concentration ( $\mu$ g.l $l^{-1}$ ) using the following conversion factors:

$1 B q . l^{-1}=27.0$ pCi.l-1; $=1 \mu g l^{-1}=\frac{1 C i . l^{-1}}{0.67}$

\subsection{Risk Assessment}

In the present investigation, two types of risks associated with uranium were evaluated. One is the radiological risk due to uranium as a radioactive element, and the second is the chemical toxicity due to uranium as a heavy metal.

\subsubsection{Radiological Risk Assessment}

The radiological risk was calculated using the USEPA method (USEPA, 2000). The

Lifetime excess cancer risk, ECR associated with intake of uranium nuclide was estimated from the product of the applicable risk coefficient $r$ and the per capita activity intake I expressed below.

Risk factor, $R=r \times I$

Thus ECR = Activity Con. Of Uranium $(A c) \times$ Risk factor $(R)$

According to WHO (2016), the average life expectancy at birth in Nigeria is $54.5 \mathrm{y}$ and, an annual consumption of water for an individual is about $730 \mathrm{l}$. This brings the lifetime intake of water to 39,785 $\mathrm{l}$. The cancer risk coefficients of uranium of $1.13 \times 10^{-9}$ and $1.73 \times 10^{-9} \mathrm{~Bq}^{-1}$ for mortality and morbidity respectively were obtained from the literature (USEPA, 1999; UNSCEAR, 2000). Using equation 4 and these coefficients, the cancer mortality and morbidity risks of uranium over lifetime consumption of water were calculated.

\subsubsection{Chemical Toxicity Risk}

The chemical toxicity risk in the drinking water samples due to the uranium concentration was estimated in terms of the $L A D D$ (lifetime average daily dose, $\mu \mathrm{g} . \mathrm{kg}^{-1}$.day-1) using the following formula (Ye-shin et al.,2004):

Ingestion LADD of Drinking water $=\frac{E P C \times I R \times E F \times E D}{A T \times B W}$

where

$L A D D=$ lifetime average daily dose $\left(\mu \mathrm{g} \cdot \mathrm{kg}^{-1} \cdot\right.$ day $\left.^{-1}\right), E P C=$ exposure point concentration $(\mu \mathrm{g} / \mathrm{l}), I R=$ water ingestion rate (l/day), $E F=$ exposure frequency (days/year),

$E D=$ total exposure duration (years), $A T$ = average time (days) and

$B W=$ body weight. 
The chemical toxicity will therefore be evaluated using the lifetime average daily dose (LADD) of uranium through drinking water intake estimated in equation (5) by comparing it to the reference dose (RFD) of $0.6 \mu \mathrm{g} \cdot \mathrm{kg}^{-1}$.day-1 (Ye-shin et al., 2004). This ratio produces a hazard quotient as shown in equation (6). Hazard quotient below unity implies that adverse effects are very unlikely to occur. However, if $\mathrm{HQ}>1.00$, then the lifetime average daily dose of metal exceeds the reference dose, indicating that there is a potential risk associated with the metal.

Hazard Quotient $(H Q)=\frac{L A D D}{R F D}$

\section{Results and Discussion}

\subsection{Activity Concentration and Mass Concentration}

The result of the activity and mass concentrations of uranium for both the bottled water samples and the well water samples are present of the samples are presented in Table 1 below.

\begin{tabular}{|c|c|c|c|}
\hline SAMPLE & ${ }^{238} \mathrm{U}\left(B q . I^{-1}\right)$ & ${ }^{238} \mathrm{U}\left(\mathrm{pCi.1}{ }^{-1}\right)$ & ${ }^{238} \mathrm{U}\left(\mu g l^{-1}\right)$ \\
\hline BW1 & $6.83 \pm 2.64$ & 184.41 & 274.77 \\
\hline BW2 & $15.88 \pm 0.42$ & 428.76 & 638.85 \\
\hline BW3 & $13.86 \pm 0.71$ & 374.22 & 557.59 \\
\hline BW4 & $12.34 \pm 0.87$ & 333.18 & 496.44 \\
\hline BW5 & $9.60 \pm 2.51$ & 259.2 & 386.20 \\
\hline BW6 & $11.92 \pm 0.85$ & 321.84 & 479.54 \\
\hline BW7 & $12.48 \pm 0.81$ & 336.96 & 502.07 \\
\hline BW8 & $18.61 \pm 0.64$ & 502.47 & 748.68 \\
\hline BW9 & $13.38 \pm 0.49$ & 361.26 & 538.28 \\
\hline BW10 & $13.09 \pm 0.79$ & 353.43 & 526.61 \\
\hline BW11 & $14.79 \pm 0.54$ & 399.33 & 595.00 \\
\hline BW12 & $11.89 \pm 0.37$ & 321.03 & 478.33 \\
\hline BW13 & $13.86 \pm 0.30$ & 374.22 & 557.59 \\
\hline BW14 & $9.64 \pm 2.42$ & 260.28 & 387.82 \\
\hline BW15 & $14.36 \pm 0.61$ & 387.72 & 577.70 \\
\hline WW1 & $16.63 \pm 0.39$ & 449.01 & 669.02 \\
\hline WW2 & $12.88 \pm 1.98$ & 345.6 & 514.94 \\
\hline WW3 & $12.95 \pm 0.22$ & 349.65 & 520.98 \\
\hline WW4 & $14.56 \pm 0.02$ & 393.12 & 585.75 \\
\hline WW5 & $17.31 \pm 0.17$ & 467.37 & 696.38 \\
\hline WW6 & $18.23 \pm 0.64$ & 492.21 & 733.39 \\
\hline WW7 & $16.26 \pm 0.87$ & 439.02 & 654.14 \\
\hline WW8 & $17.29 \pm 0.48$ & 466.83 & 695.58 \\
\hline WW9 & $14.98 \pm 0.18$ & 404.46 & 602.65 \\
\hline
\end{tabular}

Table 1: Activity Concentration and Mass Concentration of Uranium in the Bottled Water (BW) and Well Water (WW) in the Study Area

\subsubsection{Bottled Water (BW), Well Water (WW)}

The activity concentration of uranium in bottled water samples ranged from $6.83 \pm 2.64$ to $18.61 \pm 0.64$ while the activity concentration of uranium in well water samples ranged from $12.88 \pm 1.98$ to $18.23 \pm 0.64$. The mass concentration values in bottled water samples ranged from 274.77 to $748.68 \mu \mathrm{gl}^{-1}$ with a mean value of $516.36 \mu \mathrm{gl}^{-1}$. The mass concentration values in well water samples ranged from 514.94 to $733.39 \mathrm{ggl}^{-1}$ with a mean value $625.05 \mu \mathrm{gl}^{-1}$. Both the values of the bottled water samples and the well water samples exceeded the recommended safe limit of uranium in drinking of $15 \mathrm{gll}^{-1}, 20 \mu \mathrm{gl}^{-1}$ and $30 \mathrm{\mu gl}^{-1}$ set by the world Health Organization (WHO, 2003), the United State Environmental Protection Agency (USEPA, 2003) and the Health Canadian (1999) respectively. The intake of this water samples may result in significant risk to health over a lifetime. These high values of mass concentration of uranium in both bottled and well water samples in the study area may be due to the presence of granite in the underlying structure of the study area as revealed in Figure 1.

\subsection{Radiological Risk Assessment}

The radiological risk in terms of lifetime cancer risk associated with the intake uranium nuclide for both mortality and morbidity were estimated and presented in Table 2. 


\begin{tabular}{|c|c|c|c|}
\hline SAMPLE & 238U(Bq.1-1) & $\begin{array}{c}\text { LifetimeCancer } \\
\text { Mortality Risk }\end{array}$ & $\begin{array}{c}\text { LifetimeCancer } \\
\text { Morbidity Risk }\end{array}$ \\
\hline BW1 & $6.83 \pm 2.64$ & $3.07 \times 10^{-4}$ & $4.7 \times 10^{-4}$ \\
\hline BW2 & $15.88 \pm 0.42$ & $7.14 \times 10^{-4}$ & $1.09 \times 10^{-3}$ \\
\hline BW3 & $13.86 \pm 0.71$ & $6.23 \times 10^{-4}$ & $9.54 \times 10^{-4}$ \\
\hline BW4 & $12.34 \pm 0.87$ & $5.55 \times 10^{-4}$ & $8.49 \times 10^{-4}$ \\
\hline BW5 & $9.60 \pm 2.51$ & $4.32 \times 10^{-4}$ & $6.61 \times 10^{-4}$ \\
\hline BW6 & $11.92 \pm 0.85$ & $5.36 \times 10^{-4}$ & $8.20 \times 10^{-4}$ \\
\hline BW7 & $12.48 \pm 0.81$ & $5.61 \times 10^{-4}$ & $8.59 \times 10^{-4}$ \\
\hline BW8 & $18.61 \pm 0.64$ & $8.37 \times 10^{-4}$ & $1.28 \times 10^{-3}$ \\
\hline BW9 & $13.38 \pm 0.49$ & $6.02 \times 10^{-4}$ & $9.21 \times 10^{-4}$ \\
\hline BW10 & $13.09 \pm 0.79$ & $5.88 \times 10^{-4}$ & $9.00 \times 10^{-4}$ \\
\hline BW11 & $14.79 \pm 0.54$ & $6.65 \times 10^{-4}$ & $1.02 \times 10^{-3}$ \\
\hline BW12 & $11.89 \pm 0.37$ & $5.35 \times 10^{-4}$ & $8.18 \times 10^{-4}$ \\
\hline BW13 & $13.86 \pm 0.30$ & $6.23 \times 10^{-4}$ & $9.54 \times 10^{-4}$ \\
\hline BW14 & $9.64 \pm 2.42$ & $4.33 \times 10^{-4}$ & $6.64 \times 10^{-4}$ \\
\hline BW15 & $14.36 \pm 0.61$ & $6.46 \times 10^{-4}$ & $9.88 \times 10^{-4}$ \\
\hline WW1 & $16.63 \pm 0.39$ & $7.48 \times 10^{-4}$ & $1.14 \times 10^{-3}$ \\
\hline WW2 & $12.88 \pm 1.98$ & $5.79 \times 10^{-4}$ & $8.87 \times 10^{-4}$ \\
\hline WW3 & $12.95 \pm 0.22$ & $5.82 \times 10^{-4}$ & $8.91 \times 10^{-4}$ \\
\hline WW4 & $14.56 \pm 0.02$ & $6.55 \times 10^{-4}$ & $1.00 \times 10^{-3}$ \\
\hline WW5 & $17.31 \pm 0.17$ & $7.78 \times 10^{-4}$ & $1,19 \times 10^{-3}$ \\
\hline WW6 & $18.23 \pm 0.64$ & $8.20 \times 10^{-4}$ & $1.25 \times 10^{-3}$ \\
\hline WW7 & $16.26 \pm 0.87$ & $7.31 \times 10^{-4}$ & $1.11 \times 10^{-3}$ \\
\hline WW8 & $17.29 \pm 0.48$ & $7.77 \times 10^{-4}$ & $1.19 \times 10^{-3}$ \\
\hline WW9 & $14.98 \pm 0.18$ & $6.73 \times 10^{-4}$ & $1.03 \times 10^{-3}$ \\
\hline
\end{tabular}

Table 2: The Estimated Lifetime Cancer Mortality and Morbidity Risk of Uranium in the Water Samples

The excess cancer mortality risk associated with the intake of uranium in the drinking water samples investigated ranged from $3.07 \times 10^{-4}$ to8.37 $\times 10^{-4}$ for the bottled water (BW) samples and from $5.79 \times 10^{-4}$ to $8.20 \times 10^{-4}$ for the well water (WW) samples. All the water samples investigated had their excess cancer mortality risk lower than the permissible limit of $10^{-3}$.

The excess cancer morbidity risk associated with the intake of uranium in the drinking water samples investigated ranged from $4.70 \times 10^{-4}$ to $1.28 \times 10^{-3}$ for the bottled water (BW) samples and from $8.87 \times 10^{-4}$ to $1.25 \times 10^{-3}$ for the well water (WW) samples. For the bottled water samples, $80 \%$ of the samples investigated fall below the permissible value of $10^{-3}$ while samples BW2, BW8 and BW11 have values above the permissible value. For the well water samples, only samples WW2 and WW3 were radiologically safe. All the other samples have their excess cancer morbidity risk higher than the permissible value.

The result of the radiological risk assessment shows that all the drinking water samples were radiologically safe in terms of the excess cancer mortality risk. Meanwhile only $80 \%$ of the bottled water samples and two of the well water samples were radiologically safe for consumption in term of the excess cancer morbidity risk.

\subsection{Chemical Toxicity Risk}

Using therefore, $\mathrm{IR}=2$ l.day- $1 ; \mathrm{EF}=350$ days, $\mathrm{ED}=54.5 \mathrm{y}, \mathrm{AT}=19,892.5$ (obtained from $54.5 \times 365$ ) and BW $=70$ $\mathrm{kg}$ (for a standard man) and by comparing the lifetime average daily dose (LADD) obtained in this study and the reference dose (RFD) ( $0.6 \mu \mathrm{g} \cdot \mathrm{kg}^{-1}$. day-1) that is an acceptable level, the chemical toxicity risk due to uranium in the water samples over a lifetime consumption were estimated in terms of the hazard quotient. Therefore, the estimated exposure and the hazard quotient due to intake of water to the population of Iluju are presented in Table 3. 


\begin{tabular}{|c|c|c|}
\hline Sample & $\begin{array}{c}\text { Lifetime Average Daily } \\
\text { Dose (Mg.Kg-1.Day-1) }\end{array}$ & Hazard Quotient (Hq) \\
\hline BW1 & 7.53 & 12.55 \\
\hline BW2 & 17.50 & 29.17 \\
\hline BW3 & 15.28 & 25.47 \\
\hline BW4 & 13.60 & 22.67 \\
\hline BW5 & 10.58 & 17.63 \\
\hline BW6 & 13.14 & 21.90 \\
\hline BW7 & 13.76 & 22.93 \\
\hline BW8 & 20.51 & 34.18 \\
\hline BW9 & 14.75 & 24.58 \\
\hline BW10 & 14.43 & 24.05 \\
\hline BW11 & 16.30 & 27.17 \\
\hline BW12 & 13.11 & 21.85 \\
\hline BW13 & 15.28 & 25.47 \\
\hline BW14 & 10.63 & 17.72 \\
\hline BW15 & 15.83 & 26.38 \\
\hline WW1 & 18.33 & 30.55 \\
\hline WW2 & 14.11 & 23.52 \\
\hline WW3 & 14.27 & 23.78 \\
\hline WW4 & 16.05 & 26.75 \\
\hline WW5 & 19.08 & 31.80 \\
\hline WW6 & 20.09 & 33.48 \\
\hline WW7 & 17.92 & 29.87 \\
\hline WW8 & 19.05 & 31.75 \\
\hline WW9 & 16.51 & 27.52 \\
\hline & & 25 \\
\hline
\end{tabular}

Table 3: The Estimated Lifetime Average Daily Dose and the Hazard Quotient for All the Water Samples

The lifetime average daily dose (LADD) ranged from $7.53-20.51 \mu \mathrm{g} . \mathrm{kg}^{-1}$.day-1. The LADDs values were observed higher in the well water samples than in the bore hole water samples. However the LADDs obtained for all the water samples were above the reference dose (RFD) of $0.6 \mu \mathrm{g} \cdot \mathrm{kg}^{-1}$.day ${ }^{-1}$. Similarly, the hazard quotient for all the water samples investigated ranged from 12.55 to 34.14 . The hazard quotient for all the drinking water samples investigated were found to be far above the threshold value of unity as suggested by USEPA (1993). This implies thatthere is a potential risk associated with the uranium in the water samples

\section{Conclusion}

The activity concentration of uranium in bottled and well water samples in Iluju area, Ogbomoso, Nigeria were measured using gamma ray spectroscopy method. The activity concentration of uranium in the bottled water samples ranged from $6.83 \pm 2.64$ to $18.61 \pm 0.64$ while that of well water samples ranged from $12.88 \pm 1.98$ to $18.23 \pm 0.64$. The mass concentration values in the bottled water samples ranged from 274.77 to $748.68 \mu \mathrm{gl}^{-1}$ and that of well water samples ranged from 514.94 to $733.39 \mathrm{gl}^{-1}$. Both the mass concentration values of the bottled water samples and the well water samples exceeded the recommended safe limit of uranium in drinking water of many agency. The excess cancer mortality risk associated with the intake of uranium in the drinking water samples investigated ranged from $3.07 \times 10^{-4}$ to8.37 x $10^{-4}$ for the bottled water samples and from $5.79 \times 10^{-4}$ to $8.20 \times 10^{-4}$ for the well water samples. All the water samples investigated had their excess cancer mortality risk lower than the permissible limit. The excess cancer morbidity risk associated with the intake of uranium in the drinking water samples investigated ranged from $4.70 \times 10^{-4}$ to $1.28 \times 10^{-3}$ for the bottled water samples and from $8.87 \times 10^{-4}$ to $1.25 \times 10^{-3}$ for the well water samples. Thus, only $80 \%$ of the bottled water and $22 \%$ of the well water samples were safe in term of the excess cancer morbidity risk. All the water samples were found to be unsafe in terms of their chemical risk and they all exceeded the hazard quotient of unity. Therefore, the risk associated with drinking bottled water and well water in Iluju, Ogbomoso is due to cancer morbidity risk and chemical toxicity risk and may pose serious threat to the local people.

\section{References}

i. Australia and New Zealand Standards (AS/NZS) (1998). Water quality - Sampling Guidance on the design of sampling programs, sampling techniques and the preservation and handling of samples (AS/NZS5667-1).

ii. Awudugba AO, Tchokossa P (2008). Assessment of Radionuclide Concentrations in Water Supply from Bore-holes in Ogbomoso land, Western Nigeria; Ind and Buil. Environ., 17(2): 183-186. 
iii. Domingo J.L. et al. (1989) The development toxicity of uranium in mice, Toxicology 55, 143 -152.

iv. Dang H.S., Jaiswal D.D., Parameswaran M., Deodhar K.P., Krishnamony S. (1996) Age Dependent Physical and Anatomical Indian Data for application in Internal Dosimetry, Radiat. Prot.Dosim. 63, 217-222.

v. Guglielmotti M., Ubios A, Larumbe J, Cabrini R. (1989) Tetracycline in uranyl nitrate intoxication: its action on renal damage and U retention in bone, Health Phys. 57, 403-405.

vi. Larivière D. et al. (2007) Age dependence of natural uranium and thorium concentrations in bone, Health Phys. 92, 119-126.

vii. Leggett R.W. (1989) The behavior and chemical toxicity of uranium in the kidney: a reassessment, Health Phys. 57, 365-383.

viii. Jibiri NN, Mabawonku AO, Oridate AA, Ujiagbedion CA (1999). Natural radionuclide concentration levels in soil and water around a Cement factory at Ewekoro, Ogun, Nigeria: Nig. J. Phy., 11: 12-16.

ix. Jibiri NN, Farai IP, Alausa SK (2007) Estimation of annual effective dose due to Natural radioactive elements in ingestions of foodstuffs in tin mining area of Jos-Plateau, Nigeria: J. Environ. Radioactivity, 94: 31- 40.

x. Jibiri NN, Alausa SK, Farai IP (2009). Assessment of external and internal doses due to farming in high background radiation areas in old tin mining localities in Jos-Plateau, Nigeria. Radioprotection, 44: 139-151.

xi. Health Canada (1999). Summary of guidelines for Canadian drinking water quality: Prepared by federal provincial subcommittee on drinking water of the federal provincial-territorial committee on environmental and occupational health.

xii. Keith M.S., Spoo W., Corocoran J. (1999) Toxicological profile for uranium (update). ATSDR, US Department of Health and Human Services, Atlanta, Georgia, USA.

xiii. Kurttio P. et al. (2002) Renal effects of uranium in drinking water, Environ. Health Perspect. 110 (4), $337-342$.

xiv. Sahoo S.K. et al. (2009) Distribution of uranium in drinking water and associated age-dependent radiation dose in India, Radiat. Prot. Dosim. 136, 108-113.

xv. United State Environmental Protection Agency (1989) Health Effect Assessments Summary Tables (HEAST) and user's Guide, Office of Emergency and Remedial Response, US Environmental Protection Agency, Washington DC,

xvi. USA.

xvii. United State Environmental Protection Agency (1993) Carcinogenicity assessment. IRIS (Integrated Risk Information System), 2003; US Environmental Protection Agency, Washington, DC, USA. Internet: www.epa.gov/iris.

xviii. United State Environmental Protection Agency (1999). Cancer risk coefficients for Environmental exposure to radionuclides. United State Environmental Protection Agency. Federal Guidance Report No -13 (EPA. 402 R-99001).

xix. United State Environmental Protection Agency (2000) National Primary Drinking Water Regulations; Radionuclides, Final Rule. 40 CFR parts 9,141 and 142, pp. 76708-76712.

xx. United State Environmental Protection Agency (2003) Current Drinking Water Standards, Ground water and drinking water protection agency, pp 1-12.

xxi. World Health Organization (1998) World Health Organization, Guidelines for Drinking water quality, Addendum to volume 2, WHO, Geneva.

xxii. World Health Organization (WHO) (2003). Guidelines for drinking water quality Health criteria and other supporting information, Geneva, 2nd edn., 2: 367-370.

xxiii. World Health Organization (2004) Guidelines for Drinking-water Quality: Recommendations by World Health Organization, Edition: 3, Published by World Health Organization.

xxiv. World Health Organization (2008) World Health Organization, Meeting the MDG drinking water and sanitation target: the urban and rural challenge of decade.

xxv. World Health Organization (2011) Guidelines for Drinking-water Quality: Chemical hazards in drinking-water Uranium, Edition: 4, Published by World Health Organization.

xxvi. World Health Organization (2016) World Health Statistics: Monitoring Health for the SDGs. WHO Library Cataloguing-in-Publication Data. Published by World Health Organization.

xxvii. Ye-shin K, Hoa-sung P, Jin-yong K, Sun-ku P, Byong-wook C, Ig-hwan S, Dong-Chun S (2004). Health risk assessment for uranium in Korean groundwater. J. Environ. Radioactivity, pp. 77-85. 